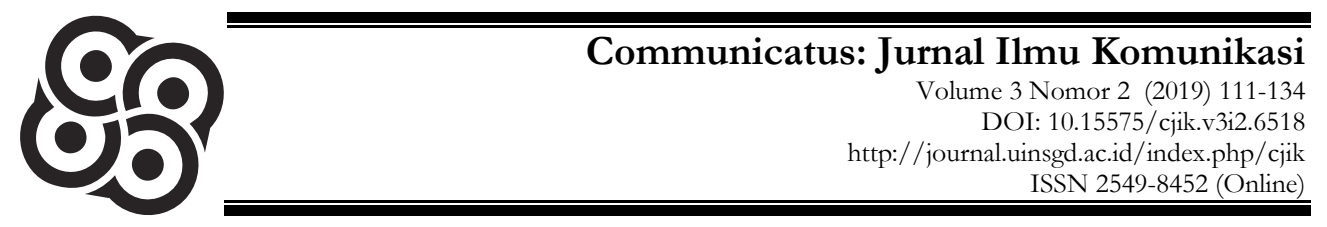

\title{
Pola Reka Bentuk Surat Kabar Thailand dan Surat Kabar Indonesia
}

\author{
Miss Aminah Sa-Ah ${ }^{1}$, Hikmat Hikmat ${ }^{2}$, \& Darajat Wibawa ${ }^{3}$ \\ ${ }^{1}$ Thairath Thailand \\ ${ }^{23}$ UIN Sunan Gunung Djati Bandung \\ *email.missaminabs-ab@gmail.com
}

\begin{abstract}
Newspaper forms are the process of organizing and decorating the front page. The two design elements consist of appearance and layout, both of which have functions to decorate, beautify and arrange the front page so that it is interesting. Thairath and Tribun Jabar newspapers in arranging the front page of the newspaper using graphic design elements to make it interesting. This research uses the descriptive qualitative method. The purpose of this research is to get a picture of the second form of newspaper, namely the color, typography, and layout format. The results showed that the application of the design of print media of the Thairath newspaper and the West Java Tribune so that it would not be rigid and attract attention. The color that dominates the Thairath newspaper is green, while the Tribun Jabar newspaper is blue. The typography used in each section on the second page of the newspaper is carried out consistently in accordance with the visual hierarchy. The layout format arrangement has an impact on attracting newspapers to be read by readers.
\end{abstract}

Keywords : Newspaper, design, layout

\begin{abstract}
ABSTRAK
Reka bentuk surat kabar merupakan proses menata dan menghias halaman muka. Dua unsur reka bentuk terdiri dari perwajahan dan tata letak, kedua-duanya memiliki fungsi untuk menghias, memperindah dan menata halaman muka sehingga menarik. Surat kabar Thairath dan Tribun Jabar dalam menata halaman muka surat kabarnya menggunakan elemen desain grafis supaya menarik. Penelitian ini menggunakan meode deskriptif kualitatif. Tujuan penelitian ini adalah untuk mendapatkan gambaran tentang reka bentuk kedua surat kabar, yaitu mengenai warna, tipografi dan format layout. Hasil penelitian menunjukkan bahwa penerapan reka bentuk media cetak surat kabar Thairath dan Tribun Jabar, supaya tidak kaku dan menarik perhatian. Warna yang menjadi dominasi pada surat kabar Thairath adalah warna hijau, sementara pada surat kabar Tribun Jabar adalah warna biru. Tipografi yang digunakan pada setiap bagian halaman muka kedua surat kabar, dilakukan secara konsisten sesuai dengan hierarki visual. Penataan format layout berimbas pada menariknya surat kabar untuk dibaca oleh pembaca.
\end{abstract}

Kata kunci : Surat kabar, reka bentuk, layout

Diterima: Agustus 2019. Disetujui: Oktober 2019. Dipublikasikan: Desember 2019 


\section{PENDAHULUAN}

Reka bentuk media cetak merupakan proses penyusunan elemen-elemen desain ke dalam bidang cetak sehingga memunculkan kesan estetik dan artistik. Reka bentuk juga merupakan manajemen bentuk dan bidang dalam merancang perwajahan dan tata letak. Reka bentuk merupakan proses yang dirancang secara menarik. Oleh karena itu perlu konsep yang matang agar hasilnya mewrujudkan perwajahan dan penataan halaman yang menarik dan memikat.

Perwajahan dan tata letak merupakan salah satu kegiatan dalam proses penerbitan media cetak yang bertujuan untuk menghias, memperindah halaman surat kabar sehingga nyaman dilihat sehingga memiliki daya tarik untuk dibaca konsumen media massa. Pembaca juga mudah mendapatkan berita yang di anggap penting. Oleh karena itu perwajahan diperlukan oleh setiap media cetak seperti koran, majalah, atau buku.

Tujuan reka bentuk media adalah menampilkan elemen-elemen gambar dan teks agar komunikatif sehingga dapat memudahkan pembaca dalam menerina informasi yang disajikan (Darsono dan Muhaemin 2013:7). Reka bentuk surat kabar kinerjanya ditentukan oleh desain yang baik (Prayanto (2017).

Perwajahan media cetak, misalnya buku, pernah diteliti oleh Mahdamy (2015) terhadap buku Promosi City Branding Kabupaten/ Kota. Hasilnya ditemukan bahwa pembuatan perwajahan tersebut dimaksudkan untuk menarik minat dan diterima kalangan muda dan masyarakat umum. Perhatian khusus yang diberikan oleh penerbit terhadap reka bentuk surat kabar memiliki maksud agar surat kabarnya laku di pasaran dan dikenal masyarakat luas.

Reka bentuk surat kabar merupakan elemen terpenting dalam kesan keseluruhan pada penerbit. Reka bentuk surat kabar bukan hanya sebagai pembungkus sebuah produk tetapi sebagai produk itu sendiri. Reka bentuk menunjukkan karakter, gaya, ciri khas dan kesan tersendiri surat kabar tersebut.

Reka bentuk media cetak bertujuan menghasilkan desain komunikasi visual yang kreatif dan komunikatif sehingga mempu meningkatkan daya tarik pembaca terhadap visualisasi media (Hardiansyah, Arifin, dan Aswar, 2017).

Tim kreatif akan berusaha semaksimal mungkin agar mendapat konsumen, hal tersebut menyebabkan terjadinya persaingan antar surat kabar sehingga masing-masing surat kabar berusaha menyajikan berita sebaik-baiknya disertai penataan perwajahan dan tata letak yang menarik. Harapannya agar masyarakat menjadikan surat kabar sebagai sarana utama mendapatkan informasi atau berita yang diinginkan. Penyajian pada halaman muka surat kabar terdiri dari isi berita dengan kemasan yang menarik. 
Berkaitan antara reka bentuk dengan pembaca Arianti, Slamet, dan Andrianto (2017), melakukan penelitian terhadap pentingnya reka bentuk, lebih spesifiknya desain layout yang menjadi bagian dari reka bentuk surat kabar. Reka bentuk tersebut menjadi bagian dari unit kepuasan pelanggan. Hasil penelitiannya menunjukkan bahwa desain layout dianggap sebagai atribut paling pnting untuk dipertimbangkan oleh sebuah surat kabar. Karena menjadi daya tarik bagi pembaca.

Tahun 2005 beberapa surat kabar di Indonesia khususnya Jakarta mengubah format yang berpengaruh juga terhadap perubahan reka bentuk surat kabarnya. Perubahan ini misalnya dilakukan oleh surat kabar Tempo. Tempo mengubah format korannya dengan merujuk pada konsep McJournalism. Seperti diteliti oleh Awang Rustandi (2006). Hasil penelitiannya menyimpulkan bahwa perubahan desain dan layout surat kabar Tempo karena mengikuti tuntutan zaman.

Penelitian lainnya dilakukan oleh Ginanjar Raharja Widigda dan Imam Zaini (2014) tentang Analisis Konsep, Struktur Visual Layout 'Deteksi' pada Harian Jawa Pos edisi 15 April-15 Mei 2014. Hasil penelitiannya menunjukkan bahwa desain layout Deteksi harian Jawa Pos menampilkan layout dengan gaya anak muda yang ditunjukkan melalui warna, ilustrasi, dan tema yang diangkat. Struktur visual layoutnya menggunakan elemen yang sering muncul dengan tema yang sedang hangat. Penelitian tentang reka bentuk terkait dengan tata letak surat kabar juga pernah diteliti oleh Nova Kristiana (2016) yang melakukan penelitian terhadap tata letak media cetak lokal harian Surya.

Penelitian yang lebih spesifik terhadap reka bentuk iklan dalam surat kabar diteliti oleh Ratih Mahardika (2016) dengan judul Analisis Struktur dan Proses Komunikasi pada Seri Iklan Billboard Surat Kabar Kedaulatan Rakyat (Tema "Bebarengan Mrantasi Gawe" Versi Mbok Gendong). Penelitian tersebut lebih menekankan pada sisi komunikasinya. Hasil penelitiannya menunjukkan bahwa iklannya berhasil menyampaikan pesan tentang sebuah kondisi hidup rakyat bawah yang serba kekurangan dan keterbatasan.

Perwajahan yang baik memiliki peranan untuk menarik minat pembaca. Hal ini diperkuat oleh hasil penelitian kuantitatif oleh Arham, Koagouw, dan Onsu (2018) tentang pengaruh desain komunikasi visual surat kabar Manado Post terhadap Keputusan Membaca dari Mahasiswa Unsrat. Hasil penelitiannya menunjukkan bahwa terdapat korelasi yang kuat antara desain komunikasi visual dalam hal ini perwajahan dengan keputusan untuk membaca surat kabar. Hasil penelitiannya mengungkapkan bahwa dalam menyusun elemen grid perlu membuat klasifikasi berita dengan memahami anatomi surat kabar. Jadi penataan tata letaknya harus menarik sehingga pembaca bisa membaca berita berikut secara 
hierarkis (Yuningsih (2009).

Rahman (2016) melakukan penelitian terhadap perwajahan koran Sindo Biro Makassar. Strategi perwajahannya menekankan pada tiga jenis karakter perwajahan yaitu news, hatrick dan lifestyle. Konsep perwajahan Sindo selalu mengupayakan memasang foto jurnalistik berukuran besar yang mengambarkan isi berita dan menampilkan sebuah grafik dengan data-data yang akurat dan mendalam.

Secara mendalam, Padmasari (2018) pernah melakukan penelitian terhadap perubahan perwajahan pada Kompas sejak 1965 s.d. 2015. Hasil penelitiannya berupa pemaparan perkembangan surat kabar harian Kompas dari tahun 1965 s.d. 2015 dengan menjelaskan alasan di balik perubahan tersebut yang terkait dengan reka bentuk dari surat kabar tersebut.

Berdasarkan penjelasan sebelumnya, mendorong peneliti untuk melakukan penelitian mengenai reka bentuk media cetak yang meliputi dua hal yaitu perwajahan dan tata letak pada dua perusahaan surat kabar yaitu surat kabar Thairath Thailand dan Tribun Jabar Indonesia.

Thairath adalah salah satu surat kabar yang memiliki tingkat penjualan paling tinggi di Thailand. Awalnya diterbitkan berbentuk surat kabar mingguan yang tampil dengan format dan corak yang berfokus pada isu sosial. Berbeda dengan surat kabar mingguan lainnya yang isinya fokus pada berita politik, Thairath merupakan sebuah media nasional yang berkembang mengikuti perkembangan zaman dan teknologi. Perubahan yang dialami oleh surat kabar ini selain format surat kabar juga penggunaan warna pada rubrik-rubrik yang disajikannya.

Tribun Jabar merupakan surat kabar lokal yang diterbitkan di Jawa Barat. Walaupun belum lama berdiri, surat kabar Tribun Jabar memiliki pembaca yang tinggi. Tribun Jabar selalu menyajikan berbagai macam informasi yang sesuai dengan selera pembaca. Tribun Jabar menyajikan berita untuk kebutuhan masyarakat menengah ke bawah. Surat kabar ini termasuk salah satu surat kabar harian dari grup Kompas Gramedia.

Terkait dengan konteks penelitian, penulis mengangkat judul "Reka Bentuk Surat Kabar Thailand dan Surat Kabar Indonesia (Penelitian Deskriptif tentang Perwajahan dan Tata letak di Surat Kabar Thairath dan Surat Kabar Tribun Jabar)". Alasan tertariknya pada surat kabar ini, karena dalam pertimbangan dan desain reka bentuk pada halaman muka surat kabar Thairath dan Tribun Jabar memiliki kekhasan dan keunikan.

Reka bentuk yang diterapkan oleh kedua media cetak tersebut harus sesuai dengan segmentasinya. Peneliti memilih surat kabar Thairath dan Tribun Jabar, sebagai objek penelitian karena baik Thairath atau Tribun Jabar mempunyai segmentasi pembaca yang sama, namun kedua surat kabar tersebut memiliki tata 
perwajahan dan tata letak yang berbeda sehingga memiliki karakteristik dan kekhasan yang berbeda. Selain itu kedua-duanya merupakan surat kabar yang diminati pembaca di negaranya masing-masing. Peneliti juga tertarik dengan penerapan reka bentuk pada surat kabar Thairath dan Tribun Jabar seperti penggunaan warna, huruf, foto, judul berita, tata letak dan lainnya.

Berdasarkan uraian yang telah dikemukan pada latar belakang masalah, maka yang jadi masalah yaitu bagaimana perwajahan pada surat kabar Thairath dan Tribun Jabar? Bagaimana tata letak pada surat kabar Thairath dan Tribun Jabar?

Objek penelitian ini dirujuk dari edisi tahun 2016 dan 2017. Penelitian ini menggunakan metode analisis isi dan perbandingan pada dua surat kabar, yaitu Thairath Thailand dan Tribun Jabar Indonesia.

\section{HASIL DAN PEMBAHASAN}

Surat kabar Thairath merupakan salah satu media cetak yang lahir pada tahun 1950, dengan format lebar (broadsheed), berkategori Nasional, berdasarkan wilayah edaran yang meliputi seluruh wilayah dalam Negara Thailand. Wilayah beredarnya surat kabar Thairath meliputi 77 wilayah di Thailand. Jumlah oplahnya mencapai 1.000.000 per hari.

Tribun Jabar merupakan media cetak lokal/regional yang lahir pada tahun 2005 dan beredar di wilayah Jawa Barat. Hal ini dapat dilihat dari pemberitaan yang menyajikan peristiwa-peristiwa yang terjadi di wilayah seperti Cirebon, Garut, Ciamis, Sumedang, Tasikmalaya, Cianjur, Bandung Raya, Subang, Purwakarta, dan wilayah lainnya di Jawa Barat.

Surat kabar adalah lembaran tercetak yang memuat laporan yang terjadi di masyarakat dengan ciri-ciri terbit secara priodik, bersifat umum, isinya periodik dan aktual tentang apa yang terjadi (Effendy, 2002). Selaras dengan apa yang dilakukan oleh surat kabar Thairath dan Tribun Jabar merupakan media massa cetak yang memiliki karakteristik yang dapat membedakan dengan media lain. Perbedaan tersebut berupa penyebaran informasi secara tercetak dan diterbitkan secara berkala yaitu perhari. Diedarkan secara umum dengan menyajikan berbagai peristiwa yang aktual kepada khalayak pembaca. Fungsinya tidak hanya menyampaikan informasi kepada khalayak, dalam memenuhi fungsi mendidik, menghibur dan memengaruhi.

Menyampaikan informasi merupakan pekerjaan kedua surat kabar. Hal ini tampak terlihat pada berita-berita yang disajikan kedua surat kabar tersebut. Selain menyampaikan informasi, surak kabar Thairath dan surat kabar Tribun Jabar juga sebagai media yang mendidik sesuai dengan fungsi mendidik pembaca. Fungsi 
mendidik kedua surat kabar dilakukan secara implisit baik dalam bentuk berita, artikel atau tajuk rencana. Selain berita dan peristiwa yang disajikan dalam surat kabar Thairath dan surat kabar Tribun Jabar, hal-hal yang bersifat menghibur juga dimuat untuk mengimbangi berita-berita berat yang disajikan dengan menyajikan cerita pendek, karikatur, cerita bergambar dan sebagainya, seperti yang dijelaskan dalam hasil penelitian yang peneliti melakukan penelitian di surat kabar Thairath dan surat kabar Tribun Jabar mengenai halaman mukanya.

Peneliti menyajikan hasil penelitian ini berdasarkan pengamatan terhadap dua surat kabar tersebut, serta hasil wawancara dengan informan dari kedua surat kabar tersebut. Peneliti juga melengkapi hasil penelitian ini pada setiap penjelasan dengan tabel dan gambar-gambar yang bersangkutan dari masing-masing aspek sesuai dengan rumusan masalah. Berikut ini adalah penjelasan gambaran hasil penelitian reka bentuk halaman muka kedua surat kabar, yakni Thairath dan surat kabar Tribun Jabar yang meliputi perwajahan dan tata letak.

\section{Perwajahan Surat Kabar Thairath}

Perwajahan adalah proses artistik halaman muka surat kabar, agar menarik. Penelitian ini menjelaskan mengenai pengetahuan dan pemahaman tentang penggunaan warna dan tipografi pada halaman muka surat kabar Thairath.

Aspek pertama adalah Warna. Warna merupakan perlengkapan gambar serta mewakili suasana kejiwaan dalam berkomunikasi. Warna juga unsur yang sangat tajam menyentuh kepekaan penglihatan hingga mampu merangsang munculnya rasa haru, sedih, gembira, atau semangat dan lain sebagainya.

Penggunaan warna secara umum pada halaman muka surat kabar Thairath menggunakan warna hijau pada halaman mukanya. Warna hijau digunaan untuk logotype, dan latar belakang subjudul berita, menggunakan warna pada tulisan dengan warna hitam dan putih. Warna hijau yang digunakan ada dua yaitu hijau tua yang digunakan pada subjudul berita, dan warna hijau muda yang digunakan sebagai latar belakang judul berita lainnya.

Selain itu pada judul berita headline, menggunakan warna hitam sebagai latar belakang dengan tulisan berwarna putih yang terlihat paling menonjol pada. Menurut pendapat Hassan Edris,

"Penggunaan warna hijau pada halaman mukannya sebagai simbol identitas surat kabar Thairath, dan menggunakan warna hitam sebagai latar belakang pada berita headline untuk menonjolkan berita dan menarik perhatian pembaca akan sebuah berita yang penting, oleh karena itu, dalam halaman muka surat kabar Thairath, hanya pada berita headline yang digunakan warna hitam" (Wawancara dengan informan 14 mei 2017). 

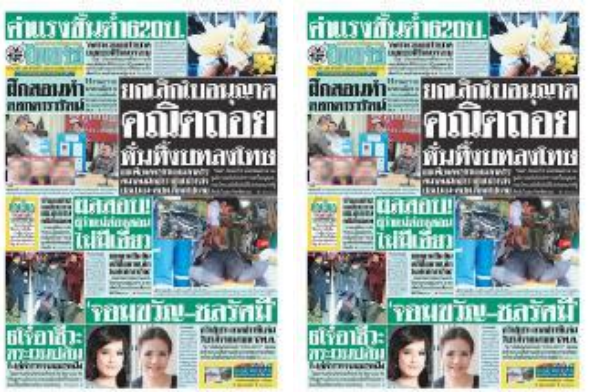

Sumber: Thairath edisi 1 Mei 2017

Gambar 1 Dominasi penggunaan warna hijau pada halaman Surat Kabar Thairath

Thairath juga menggunakan warna yang berbeda-beda pada halaman muka seperti latar belakang tulisan di bawah logo dan tulisan yang berada di atas logo yang terkenal sebagai warna harian. Penggunakan warna harian pada halaman muka meliputi warna merah, pink, kuning, hijau, orange, biru dan ungu. Warna dasar tersebut dapat dilihat pada tabel berikut ini,

Tabel 1

\section{Warna harian di Thailand}

\begin{tabular}{c|c}
\hline Hari & Warna \\
\hline Minggu & \\
Senin & \\
Selasa & \\
Rabu & \\
Kamis & \\
Jumaat & \\
Sabtu & \\
\hline
\end{tabular}

Sumber : www.baanmaha.com

Warna harian adalah salah satu budaya orang Thailand yang menerima pengaruh dari cerita orang Hindu. Warna ini berkaitan dengan perhitungan hari, bulan dan bintang. Warna harian terdiri dari 7 warna yaitu warna Merah, Kuning, Pink, Hijau, Oreng, Biru dan Ungu. Berdasarkan perhitungan hari di Thailand, yang diawali dengan hari minggu dan diakhiri dengan hari sabtu. Penggunaan warna harian surat kabar Thairath dapat dilihat pada gambar berikut; 


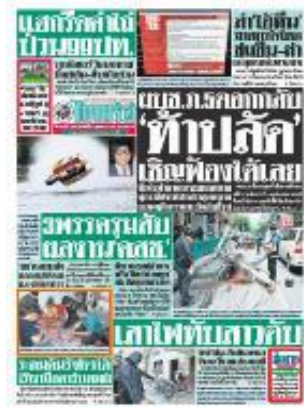

Minggu / merah

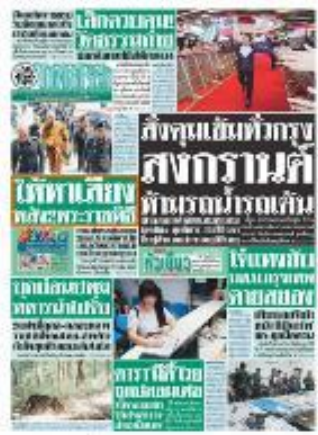

Rabu / Hijau

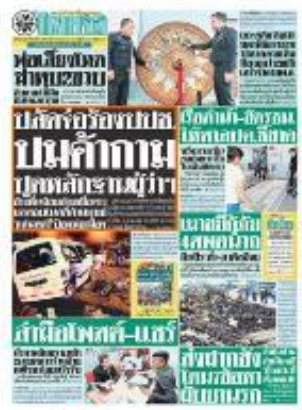

Senin / Kuning

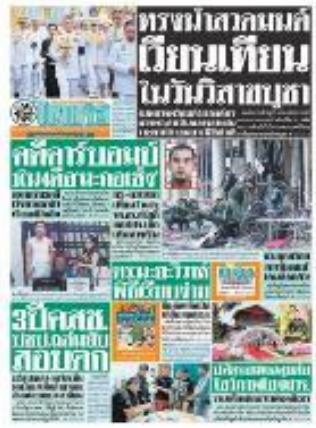

Kamis / Oreng

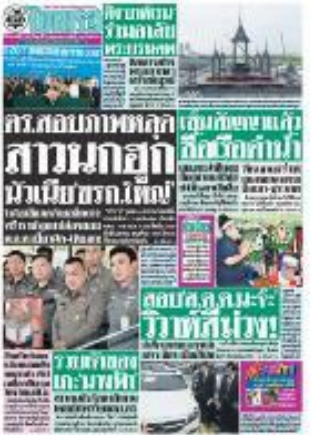

Sabtu / Ungu

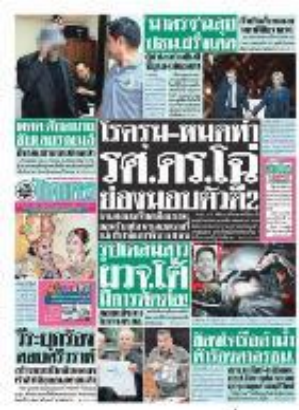

Selasa / pink

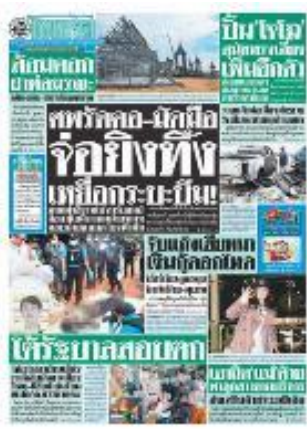

Jumaat / Biru

Sumber: Koran Harian Thairath

Gambar 2 Warna hari yang diterapkan dalam surat kabar Thairath pada halaman muka edisi hari senin hingga hari minggu

Warna memiliki peran penting untuk memperindah dan mempercantik 
halaman. Melalui warna yang tepat, perwajahan media bisa menarik minat pembaca untuk membeli dan membaca media tersebut. Secara emosional, warna bisa memberikan suasana dan memengaruhi keceriaan halaman media tersebut.

Berdasarkan hasil penelitian terhadap perwajahan surat kabar Thairath, dari sisi warna halaman muka unsurnya terlalu dominan. Walaupun hanya dua warna yaitu warna hijau dan hitam, namun penggunaannya berlebihan sehingga dapat meragukan berita yang disajikan antara berita yang paling penting (beadline) dan yang tidak terlalu penting. Penggunaan warna huruf yang berbeda warna dapat mengganggu pembaca. Setidaknya penggunaan warna pada halaman muka harus dilakukan agar halaman muka terlihat indah dan menarik. Di samping itu penggunaan warna yang pas tidak mengganggu nilai keterbacaan bagi pembaca (Darsono dan Muhaemin, 2013: 83).

Penggunaan warna secara berlebihan, bisa menimbulkan kekacauan desain. Jika warna banyak dipakai, pembaca akan terganggu saat hendak membaca isi berita. Warna yang dipakai secara efektif dapat menciptakan koneksi yang tepat. Tekstur latar belakang dengan warna juga bisa mengganggu keterbacaan teks isi (Rolnicki, 2008:297).

Warna juga menjadi penguat narasi dari setiap teks yang ditulis. Misalnya sebagai contoh penggunaan warna pada gambar, secara sensorik persepsional, gambar yang berwarna penuh akan lebih mendekati keadaan objek aslinya. Sehingga dapat menyentuh sisi emosional pembaca dibandingkan warna hitam putih. Foto dengan warna penuh juga akan memunculka sensasi aktual dibanding dengan foto hitam putih yang berkesan lawas (Syuderajat, 2017: 1).

Aspek kedua Tipografi. Tipografi merupakan teknik menyusun dan memilih huruf yang akan digunakan untuk judul, lead, atau body text naskah berita. Pada halaman muka Thairath, penyajian berita dilakukan dalam bentuk kotakkotak, tidak dilakukan secara kolomisasi. Halaman muka Thairath terlepas dari proses rata kiri, rata kanan, rata tengah dan seimbang pada huruf yang digunakan pada setiap beritanya. Berita yang dimuat Thairath disajikan dengan menggunakan jenis dan ukuran berbeda-beda pada setiap berita.

Penampilan jenis huruf yang berbeda pada berita headline Thairath dapat membantu pembaca mendapatkan berita yang paling penting. Tipe huruf yang besar berwarna putih dan menggunakan warna hitam sebagai latar belakang dapat menarik perhatian sehingga pembaca dapat membedakan berita headline dengan berita-berita lain.

Jenis huruf yang digunakan dalam surat kabar Thairath adalah jenis huruf yang dibuat oleh perusahaan surat kabar Thairath khusus untuk percetakan surat kabarnya. Jenis huruf yang digunakan pada logotype digunakan jenis huruf DSN 
Thairat dengan huruf tebal. Pada berita headline menggunakan jenis huruf DSN Thairat dengan ukuran huruf yang berbeda antara ukuran 28 point hingga 373 point, pada sub headline juga menggunakan jenis huruf DSN Thairat dengan ukuran antara 107 point hingga 164 point, dan pada caption berita menggunakan jenis TH Sarabun New dengan ukuran 12 point" (wawancara dengan Hassa Edris 14 mei 2017).

Huruf DSN Thairat merupakan salah satu jenis huruf Thai yang digunakan dalam surat kabar Thairath dengan bentuk huruf yang tebal, sementara TH Saraban New pada captionnya adalah salah satu jenis huruf yang digunakan sebagai huruf resmi dalam surat menyurat di Thailand.

Pengunaan tipografi pada halaman muka digunakan berbagai ukuran yang berbeda-beda. Warna yang digunakan pada huruf yang disajikan pun berbeda. Penggunaan huruf yang berbeda pada halaman muka Thairath dapat membuat pembaca pusing saat membaca berita pada halaman mukanya. Karena beberapa judul yang memiliki nilai kurang itu menggunakan ukuran huruf yang hampir sama dengan ukuran huruf yang digunakan pada berita utama. Ditambah dengan penggunaan warna sebagai latar belakang yang lebih terang daripada latar belakang yang digunakan pada berita utama, sehingga membuat pembaca terlebih dahulu membaca berita yang lain ketimbang berita yang paling penting (headline).

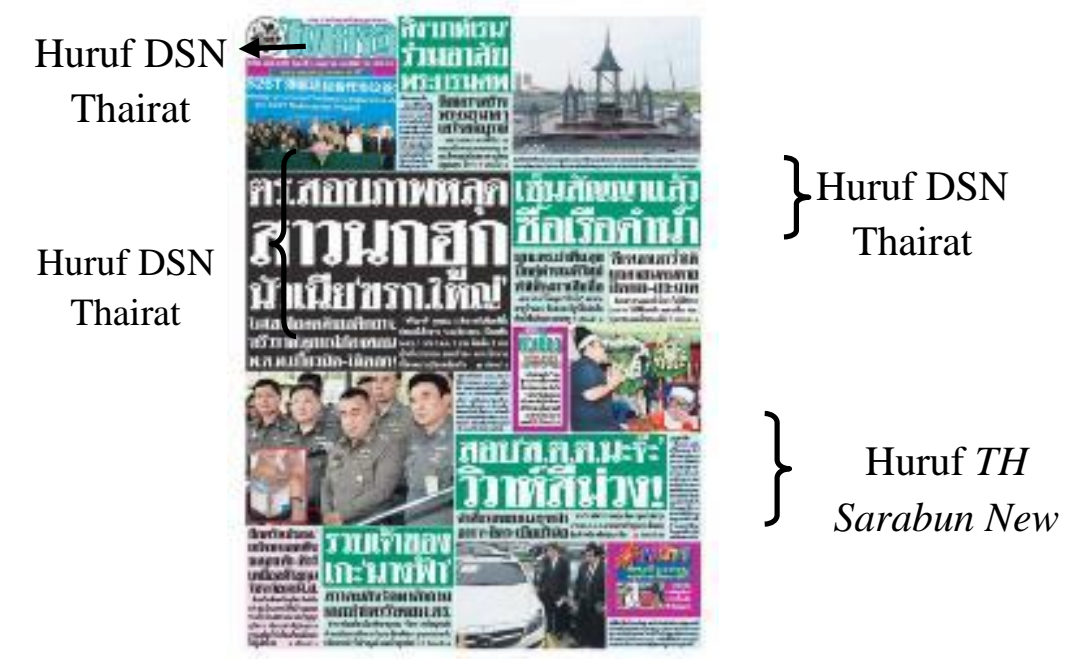

Sumber: Koran Thairath

Gambar 3 Penggunaan tipografi pada halaman muka surat kabar Thairath edisi 6 Mei 2017 


\section{Perwajahan Surat Kabar Tribun Jabar}

Penelitian ini menjelaskan mengenai pengetahuan dan pemahaman tentang penggunaan warna dan tipografi pada halaman muka surat kabar Tribun Jabar. Berdasarkan pada rujukan perwajahan, aspek pertama adalah warna. Warna memiliki peran penting pada halaman muka subuah surat kabar. Warna bisa memberikan gambaran suasana dan memengaruhi keceriaan halaman surat kabar. Namun dalam menggunakan warna pada halaman muka surat kabar itu harus dilakukan secara cermat supaya halaman muka surat kabar tersebut menarik dan tidak menggangu keterbacaan. Seperti warna yang digunakan pada halaman muka Tribun Jabar. Penggunaan warna dilakukan pada beberapa bagian, yakni warna biru digunakan pada logotype dengan posisi logonya yang ditempatkan pada bagain atas sangat menarik perhatian pembaca. Apa yang dilakukan oleh perwajahan Tribun Jabar selaras dengan pendapat yang diungkapakan oleh Januar,

"Posisi logo surat kabar Tribun Jabar ini sudah ditetapkan oleh pihak atas (Tribun), dapat dilihat dari setiap surat kabar dari Tribun, baik Tribun Jabar, Tribun Jambi, Tribun Jogja dan sebagainya. Logo pada surat kabar tersebut akan ditempatkan di bagian atas surat kabarnya. Kalau tentang penggunaan warna pada surat kabar Tribun Jabar yang kelihatannya dominan pada warna biru itu, salah satunya oleh karena warna biru adalah warna yang mewakili Jawa Barat, karena orang Bandung itu identik dengan persib Bandung. Dan warna biru juga sering digunakan oleh orang Bandung sebagai warna identitas" (wawancara informan 23 Mei 2017)

Sumber: Koran Tribun Jabar

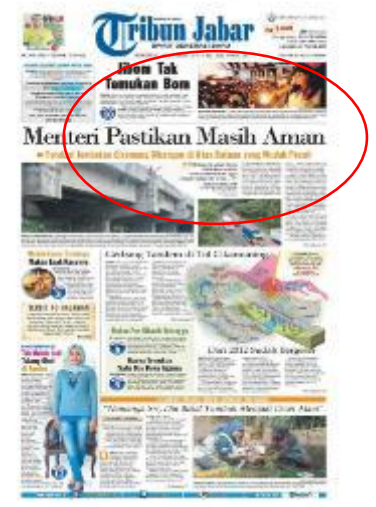

Gambar 4 Warna dominan pada halaman muka Surat Kabar Tribun Jabar edisi 25

Desember 2017 
Warna yang digunakan pada halaman muka Tribun Jabar dan latar belakang berita tidak terlalu gelap, seperti warna hijau muda dan warna cokelat muda. Sementara pada tulisan seperti pada subdujul dan kotak halaman sambung berita menggunakan berbagai warna, seperti warna cokelat dan warna abu.

Warna yang digunakan pada bagian latar belakang berita itu tergantung pada materi berita tersebut, kadang-kadang pada bagian layout ada juga yang menggunakan warna hitam. Sebenarnya penggunaan warna pada surat kabar Tribun Jabar ini tidak mempunyai aturan tertentu, warna yang digunakan itu tergantung pada bagian layout yang akan menyesuaikan warna dengan tema berita itu" (wawancara dengan Januar 23 Mei 2017).

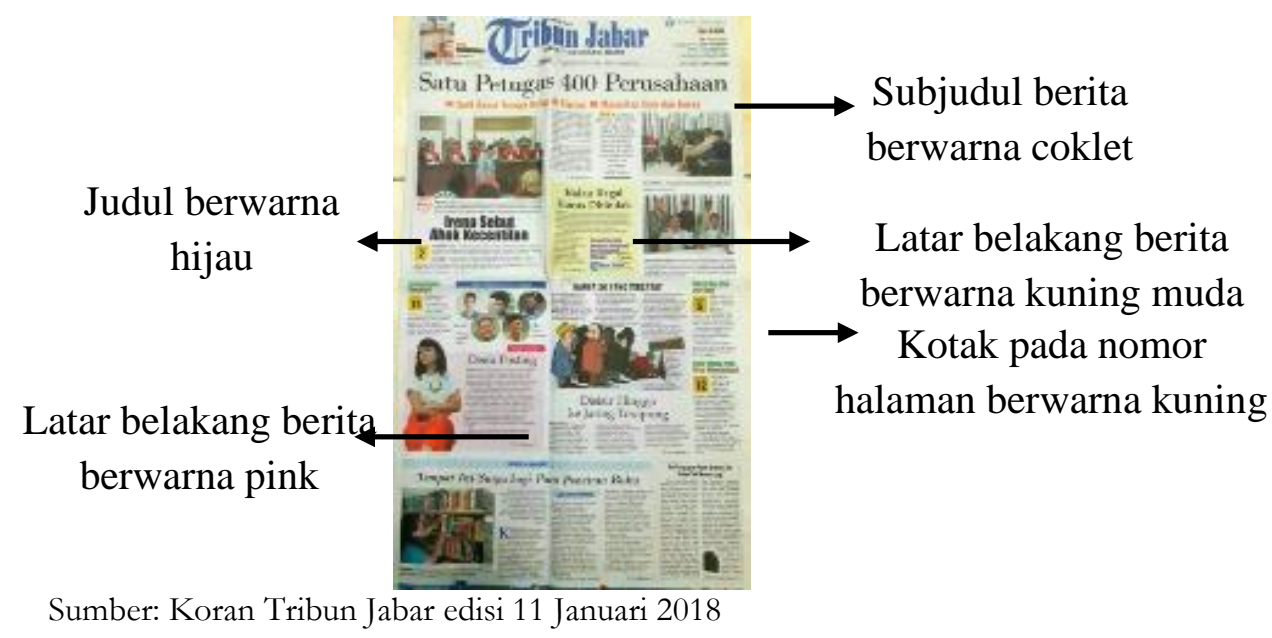

Gambar 5 Penggunan warna halaman muka Surat Kabar Tribun Jabar

Warna merupakan suatu yang mewakili suasana kejiwaan pelukisnya dalam berkomunikasi, juga merupakan unsur yang paling tajam untuk menyentuh kepekaan penglihatan sehingga mampu merangsang munculnya rasa haru, sedih, suka, semangat dan lain sebagainya. Layout adalah sebuah metode dalam menyusun atau mengorganisasi keseluruhan elemen visual dalam desain yang terdiri atas grafis (graphic), tipografi (tipography), dan ruang (space) dalam satu kesatuan desain yang mendukung fungsi media sebagai alat komunikasi (Kusrianto, 2009: 46).

Aspek kedua Tipografi. Penggunaan tipografi pada halaman muka Tribun Jabar dilakukan dengan menggunakan jenis huruf yang berbeda-beda tergantung jenis berita yang disajikan pada halaman muka. Penggunaan huruf juga dilakukan secara konsisten. Penggunaan huruf pada halaman muka surat kabar Tribun Jabar terdapat pada bagian logotypenya, pada judul berita headline, subjudul, isi berita dan 
caption. Huruf yang digunakan pada halaman depan ini ada palatino yang digunakan pada judul utama, huruf Helvetica MD BT berita indek dan huruf Arial pada subjudul juga pada caption berita. Jenis huruf pada halaman muka digunakan beda-beda, penggunaan huruf ini tidak lebih dari pada 4 jenis" (wawancara dengan Taufiq 23 Mei 2017)

Semenrata jenis huruf yang digunakan oleh surat kabar Tribun Jabar pada bagian logotype ialah huruf old English Text MT Pada huruf $\boldsymbol{T}$ dan huruf Bodoni MT Black pada tulisan Tribum Jabar. Jenis huruf pada logo surat kabar Tribun Jabar ini marupakan sebuah kebijakan yang detetapkan oleh pihak pengurus surat kabar Tribun (Wawancara Januar 23 Mei 2017). Seperti dapat dilihat pada gambar berikut:

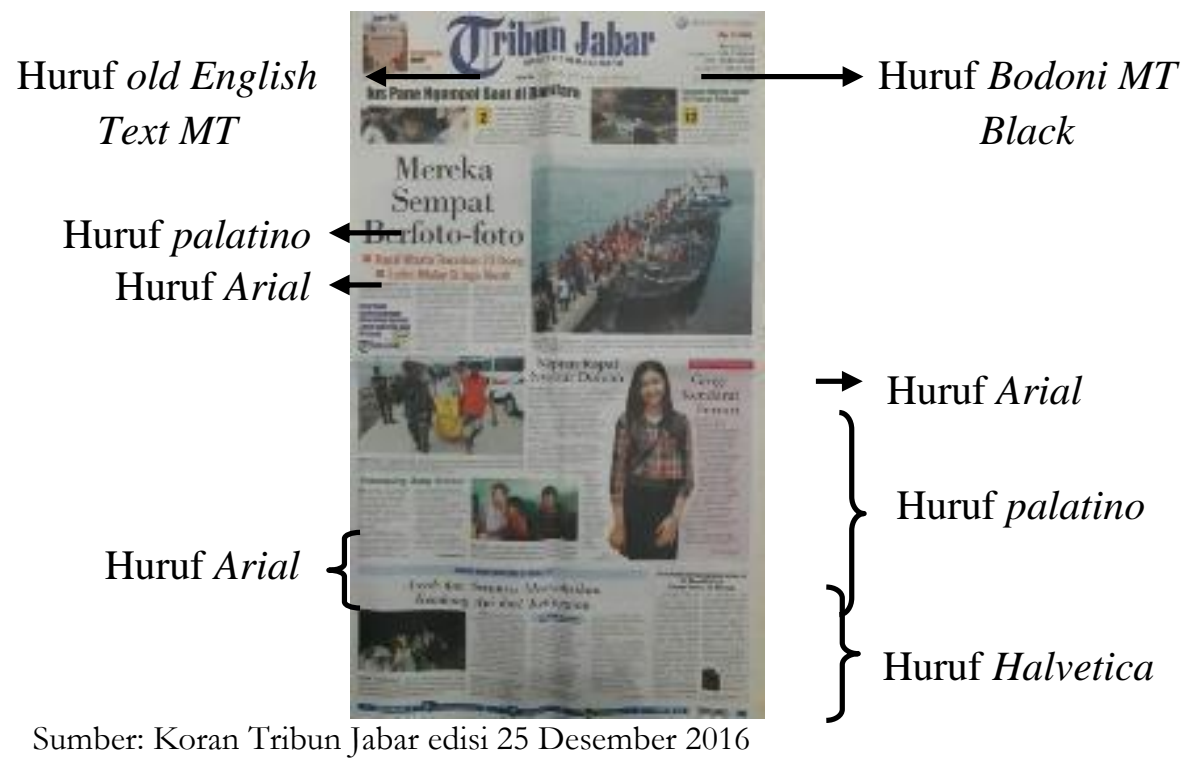

Gambar 6 Penggunaan Tipografi Pada Halaman Muka Surat Kabar Tribun Jabar

\section{Perbandingan Layout Thairath dan Tribun Jabar}

Hasil penelitian pada bagian layout Thairath, dilakukan berdasarkan pandangan peneliti terhadap perwajahan surat kabar Thairath. Berdasarkan penataan layout Thairath, dilakukan sesuai dengan jenis surat kabar yang bertipikal santai. Penataan layoutnya dilakukan dengan memainkan huruf beragam dengan ukuran berbeda pada setiap judul berita. Penggunaan warna digunakan secara mencolok. Jumlah foto yang disajikan pada halaman muka mencapai 5 foto disertai dengan foto-foto kecil yang digunakan pada bagian foto besar.

Rata-rata berita yang disajikan pada halaman muka surat kabar Thairath 
berjumlah 10 hingga 12 berita. Penggunaan jenis huruf pada halaman mukanya tidak beragam jenis, namun ukuran huruf pada setiap judul berita berbeda-beda. Penempatan berita headline diletakkan dalam bentuk kotak yang belih besar dari berita-berita lainnya. Sedangkan penyajian subjudul berita lainnya dengan menggunakan latar belakang berwarna hijau yang lebih menarik daripada berita beadline.

Penataan layout yang dilakukan oleh surat kabar Thairath adalah tampilan layout youthful style yaitu suatu bentuk layout yang memiliki kesan lucu, main-mainan dan penulisan berita headline dilakukan dengan berbagai ukuran. Quadran layout yaitu tata letak segi empat, karena apabila surat kabar ini dilipat empat, pada seperempat bagian yang tampak adalah berita pentingnya. Function layout yaitu tata telak yang setia hari berubah, tergantung pada pekembangan dan isi berita pada hari itu. Bila terjadi hal-hal yang luar biasa, sering dipakai apa yang disebut "skyline heads" yaitu ketika terjadi pemindahan nama surat kabar itu sendiri (Darsono dan Muhaemin, 2013: 76-79).

Berdasarkan format yang lebar, penyajian rata-rata 10 sampai 12 berita. Berita utama disajikan dengan ukuran kotak yang lebih besar dari berita-berita yang lain. Penggunaan warna yang berbeda pada berita utama dilakukan untuk menarik perhatian pembaca tentang suatu berita yang penting pada halaman mukanya. Huruf yang digunakan pada setiap berita pada halaman mukanya dipakai secara konsisten. Penggunaan foto kecil dipakai secara pas dan sesuai dengan peristiwa, dengan menggunakan frame berwarna merah, kuning dan kadang-kadang biru. Penataan tata layout yang dipakai oleh surat kabar Thairath dapat dilihat dari gambar berikut ini,

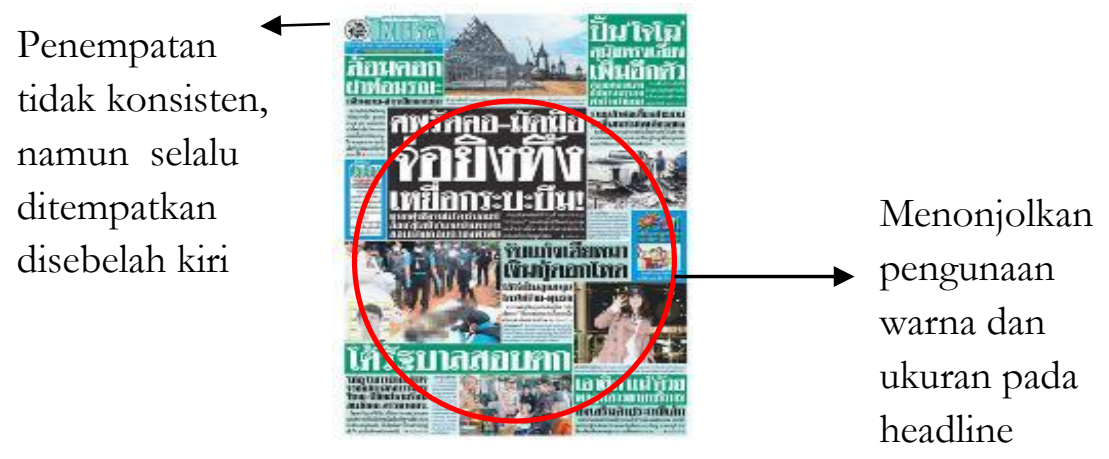

Sumber: Koran Thairath edisi 12 Mei 2017

Gambar 7 Layout Surat Kabar Thairath 
Penataan layout pada surat kabar Tribun Jabar dilakukan secara fleksibel, seperti penggunaan warna yang terlihat pada logonya. Namun ada beberapa warna yang digunakan berdasarkan jenis berita yang disajikan. Huruf yang dipakai pada setiap bagian dilakukan secara konsisten pada headline, subjudul, isi berita dan caption dengan jenis huruf yang mudah untuk dibaca. Penggunaan foto dan ilustrator dipakai untuk meletakkan halaman muka surat kabar, supaya tidak kaku dan lebih menarik.

Kebijakan layout dalam suatu surat kabar perlu dipertimbangkan secara matang, karena kebijakan ini menyangkut ciri khas atau jati diri surat kabar. Penataan layout pada halaman muka surat kabar Tribun Jabar dilakukan sesuai dengan kebijakan yang telah ditetapkan oleh bagian redaksinya.

Penataan layout yang dilakukan oleh tim, tergantung pada kreasi tim dalam melakukan penataan layout tersebut, tapi tidak terlepas dari bentuk 3-4 (tiga kolom empat kolom) yang menjadi ciri khas layout surat kabar Tribun Jabar (wawancara dengan Januar, 23 Mei 2017).

Kebijakan dalam penataan layout ada aturannya, semua aturan penataan layout terdapat pada komputer, namun aturan sifatnya dapat disesuaikan dengan kepentingan, misalnya untuk membuat judul berita sudah terdapat style seperti jenis font, ukuran font serta warna font yang pada intinya harus disesuaikan dengan berita dan style itu ditentukan oleh pihak redaksi, namun sifatnya hanya patokan saja, hanya tidak diperkenankan untuk menggunakan font yang sulit dipahami (wawancara dengan Cecep Burdansyah, 23 Mei 2017).

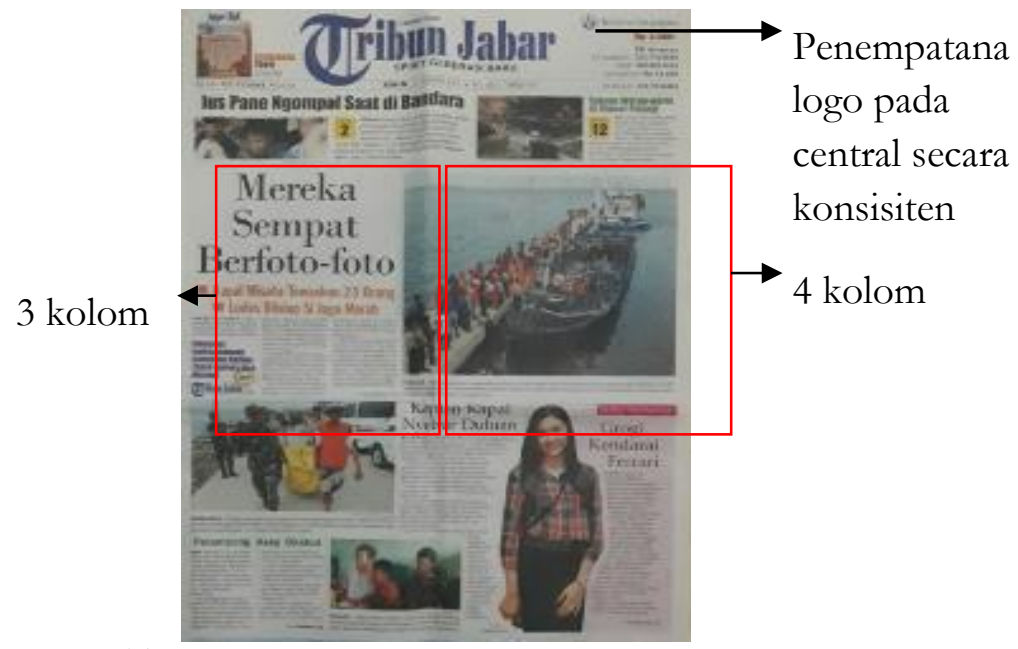

Sumber: Koran Thairath edisi 2 Januari 2017

Gambar 8 Bentuk layout tiga empat kolom 
Gambar di atas merupakan bentuk layout yang digunakan oleh surat kabar Tribun Jabar, menurut penjelasan redaktur pelaksana surat kabar Tribun Jabar. Penggunaan jenis huruf pada halaman mukanya menggunakan huruf yang mudah dibaca (tidak rumit) seperti Palatino, Arial dan helvetika. Ukuran hurufnya sesuai dengan jenis berita, seperti pada berita headline ukuran hurufnya tidak kurang dari 70 point, pada subjudul ukuran 30-35 point, pada isi berita ukuran 12-13 point dan pada captionnya ukuran hurufnya 9-10 point. Penampilan foto dengan gaya gropping dan ilustrasi untuk menghias halaman muka agar tidak kaku dan lebih menarik. Untuk lebih jelas dapat dilihat pada gambar berikut;

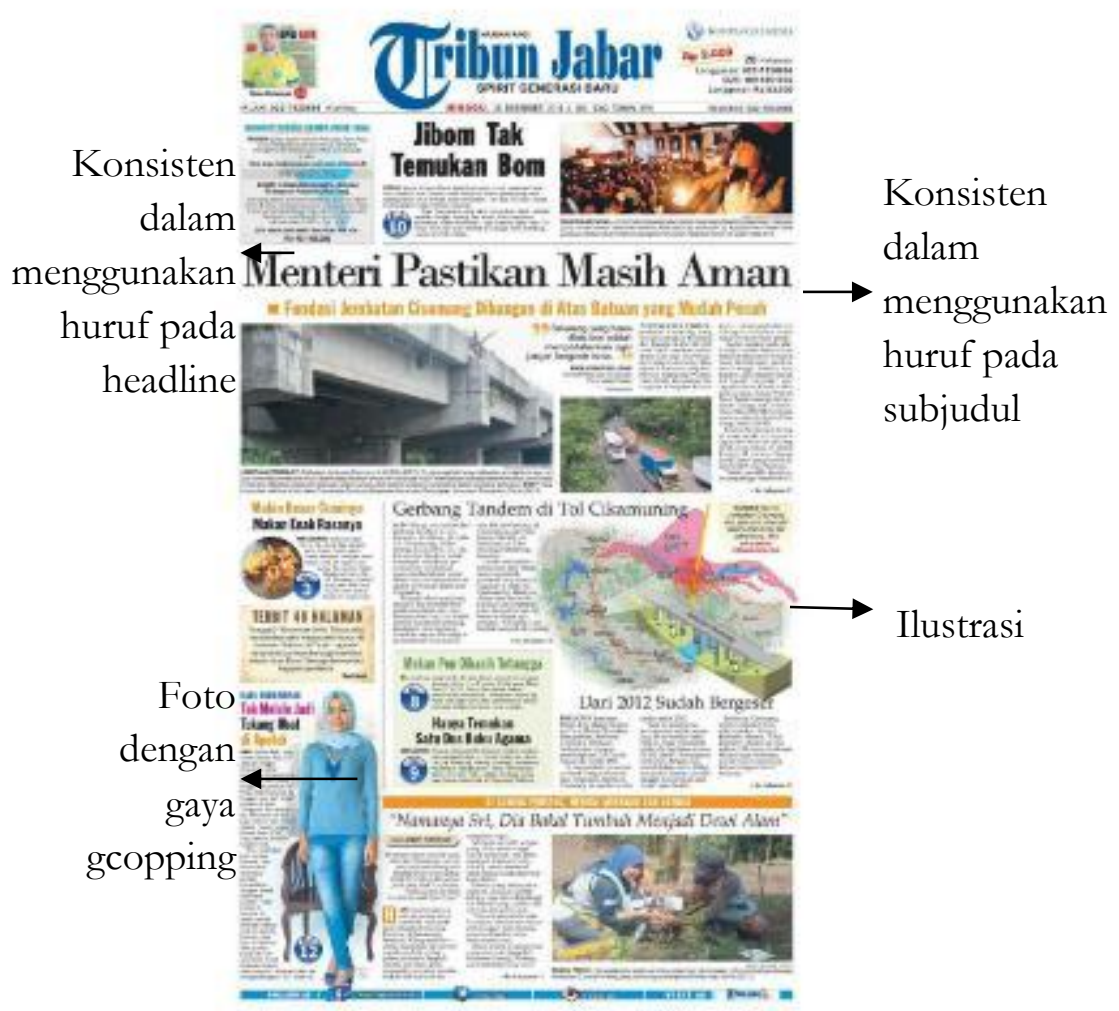

Sumber Tribun Jabar edisi Meri 2017

Gambar 9 Layut Tribun Jabar

Berdasarkan hasil penelitian di atas tentang perwajahan dan tata letak pada dua surat kabar, yaitu surat kabar Thairath dan surat kabar Tribun Jabar. Kedua media cetak tidak hanya menyajikan berbagai berita untuk menginformasi kepada 
khalayak pembaca, juga melakukan penataan halaman muka. Penataan halaman muka dilakukan dengan menggunakan warna dan huruf untuk memperindah halaman muka surat kabarnya. Hal ini dilakukan agar pembaca tertarik.

\section{Konsep Perwajahan Surat Kabar Thairat dan Tribun Jabar}

Berdasarkan hasil penelitian dari dua surat kabar yang meliputi perwajahan dan tata letak atau layout. Pembahasan mengenai perwajahan berdasarkan hasil penelitian yang telah dilakukan oleh peneliti, dan pada bagian ini akan membahas perwajahan yang meliputi aspek warna dan aspek tipografi menurut para ahli.

Aspek Warna merupakan salah satu unsur desain grafis. Sebagai perlengkapan gambar dan mewakili suasana pelukisnya dalam berkomunikasi. Warna juga merupakan unsur yang sangat penting untuk menyentuh kepekaan penglihatan sehingga mampu merangsang munculnya rasa haru, sedih, gembira, mood atau semangat dan lain-lain. Pada prinsipnya dalam dunia grafis, warna dibagi dua bagian. Pertama warna primer yang terdiri dari cyan $(\mathrm{C})$ atau biru dan merah (M) yellow (Y) dan black (K). Kedua warna sekunder yang diperoleh dari hasil campuran warna dari keempat warna primer (Kusrianto, 2009: 50).

Berdasarkan hasil penelitian pada surat kabar Thairath, penggunaan warna hitam sangat menonjol dalam penulisan berita utama. Sedangkan warna hijau menjadi warna paling banyak digunakan pada halaman muka. Pada surat kabar Tribun Jabar, dominasi penggunaan warna dilakukan hanya pada logonya yang berwarna biru dan berbagai warna lainnya yang digunakan pada halaman muka dilakukan mengikuti kesukaan tim layout.

Dominasi warna tertentu lebih memudahkan untuk mengarahkan konsentrasi saat mencerna karya tersebut dan jangan menggunakan warna-warna yang tidak saling mendukung satu sama lain dalam sebuah karya, tentukan arah warna yang dominan agar suatu karya grafis diperhatikan, dilihat, dipahami isi serta maksudnya (Kusrianto, 2009: 36).

Warna memiliki peran penting untuk memperindah dan mempercantik halaman. Melalui warna yang tepat perwajahan media bisa menarik minat konsumen untuk membeli dan membacanya. Hal ini bisa terjadi karena warna secara emosional bisa memberikan suasana dan memengaruhi keceriaan halaman media. Dengan menggunakan warna yang sesuai dengan porsinya akan membuat halaman lebih memberikan sesuatu yang hidup ketimbang sekadar menggunakan tinta hitam.

Secara visual warna memiliki kekuatan yang mampu memengaruhi citra orang yang melihatnya. Menurut Molly E. Holzschlag, seorang pakar tentang warna dalam tulisannya creating color scheme menjelaskan mengenai respons 
psikologis yang ditimbulkan dari warna, yaitu; waarna biru adalah warna yang memberi respons tentang kepercayaan, konservatif, keamanan, teknologi, kebersihan dan perintah; warna hitam adalah warna yang memberi respons mengenai kekuatan, seksualitas, kemewahan, kematian misteri, ketakutan da keanggunan; warna hijau adalah warna yang memberi respons tentang alami. Kesehatan, pandangan yang enak dan pembaruan (Kusrianto, 2009: 47).

Hal di atas merupakan unsur simbolik dari komunikasi visual yang dilakukan dengan tujuan untuk mengemukakan apa yang ingin disampaikan kepada orang lain. Komunikasi bisa dilakukan dengan berbicara, kata-kata (komunikasi verbal) dan juga melalui gambar, lambang tulisan dan bahasa isyarat (komunikasi nonverbal). Keduanya merupakan cara untuk berkomunikasi antara manusia, namun manusia juga mempunyai cara berkomunikasi yang unik mengikuti budaya masing-masing.

Warna sering digunakan untuk menunjukkan suasana emosional, cita rasa, afiliasi, politik dan keyakinan agama. warna juga mempengaruhi suasana hati, yaitu; Warna biru adalah warna yang mencerminkan suasana hati yang kalem, aman damai, lembut menenangkan dan tenteram; warna hitam adalah warna yang mencerminkan suasana hati yang berkuasa, kuat dan bagus sekali; warna hijau adalah warna yang mencerminkan suasana hati yang kalem, damai dan tenteram (Mulyana, 2010: 429).

Selaras dengan penelitian yang telah dilakukan oleh Abdul Khalik (2018), menjelaskan bahwa warna tersebut termasuk ke dalam ketegori warna dingin. Kategori warna tersebut terbagi dua, yaitu warna dingin dan warna hangat. Warna dingin adalah warna yang memberi ketenangan; warna ungu, biru dan hijau. Sementara warna hangat atau warna panas adalah warna yang cenderung memberi semangat; merah jingga dan kuning.

Selaras yang disampaikan informan menyatakan, warna yang digunakan pada halaman muka surat kabarnya. Selain untuk menarik perhatian pembaca, juga memperkenalkan identitas surat kabar. Walaupun dalam penggunaan warna pada halaman muka surat kabarnya, ada yang melakukan berdasar warna kesukaan tim layout. Namun hal itu dilakukan pada sebagian kecil halaman muka sehingga tidak menghilangkan identitasnya.

Penggunaan warna secara berlebihan, bisa menimbulkan kekacauan desain. Jika warna banyak dipakai, pembaca akan terganggu saat hendak membaca berita. Warna yang dipakai secara efektif dapat menciptakan koneksi yang tepat. Tekstur latar belakang dengan warna juga bisa mengganggu keterbacaan teks isi. Hal ini tampak terlihat dari surat kabar Thairath (Rolnicki, 2008: 297).

Selain warna, terdapat aspek tipografi surat kabar, yaitu suatu proses seni 
untuk menyusun bahan publikasi dengan menggunakan huruf cetak (Darsono dan Muhaemin 2013: 88). Tipografi adalah suatu proses seni untuk menyusun bahan publik dengan menggunakan huruf cetak, "menyusun" meliputi merancang bentuk huruf cetak hingga merangkainya dalam sebuah komposisi yang tepat untuk memperoleh suatu efek tampilan yang dikehendaki. Prinsip-prinsip dasar tipografi dalam penyusunan halaman terdiri: judul (nama media), berita utama (headline) dan subhead (Kusrianto, 2009: 209).

Berdasarkan penjelasan di atas, menunjukkan bahwa penggunaan tipografi yang dilakukan oleh surat kabar Tribun Jabar pada bagian headline sesuai dengan penjelasan tersebut. Hal ini baik penggunaan huruf kapital judul beadline dan ketika judul headline membentang di atas beberapa kolom, mereka memenuhi hingga akhir lebar kolom.

Penggunaan tipografi yang dilakukan oleh surat kabar Thairath tidak sesuai, karena huruf yang digunakan pada subhead di halaman muka surat kabar tersebut ukuran hurufnya hampir sama dengan ukuran huruf yang di gunakan pada headline.

Para ahli mengkelompokkan jenis desain huruf sesuai ciri masing-masing bagian tersebut. Ada 4 kelompok huruf sesuai dengan ciri-ciri antominya yaitu; Pertama, oldstyle adalah huruf yang dicipta oleh Aldus Manutius dari itali dan Casion di jerman, dan huruf yang dapat dikategorikan ke dalam kelompok oldstyle adalah bembo, bauer text, cg cloister, itc usherwood, claren-don, garamood, goudy oldstyle dan palatino (Lazlo Moholy dalam Adi Kusrianto, 2009: 191).

Kedua, Modern adalah huruf yang dicipta oleh Giambastita Bodoni yang menciptakan juga huruf bodoni, dan huruf yang dapat dikategorikan ke dalam kelompok modern di antaranya bodoni, bauer bodoni, didot, torino, auriga, itc fenice, lnotype modern, itc modern, walbaum book, itc zapt book, bookman, cheltenham dan melior.

Ketiga, Slab Serif adalah huruf yang ditandai dengan bentuk serif yang tebal, bahkan sangat tebal. Masa kemunculan jenis huruf itu bervariasi dan ikut menandai kemunculan huruf-huruf yang berfungsi lebih tepat sebagai penarik perhatian yaitu digunakan sebagai header, dan huruf yang dapat dikategorikan ke dalam Slaf serif antara lain boton, aachen, calvert, lubalin graph, memphis, rockwell, serifa, clarendon dan stymei.

Keempat, Sans Serif adalah huruf tanpa serif (kait di ujung) pertama kali jenis huruf ini dicipta oleh Willaian Casion IV, pada awalnya jenis huruf ini disebut Grotesque karena pada zaman itu bentuk huruf tampa sarif itu terasa aneh dan unik, dan huruf yang dapat dikategorikan ke dalam Sans Serif seperti Franklin Githic, Akzident Grotesk, Helvatica, Univers, Formata, Avent Garde, Gill Sans, Future dan Optima.

Berdasarkan penjelasan dari Lazlo Moholy Tom E. Rolnicki, Daw Tate, dan 
Tayrol, selaras dengan hasil penelitian tipografi yang digunakan pada surat kabar Tribun Jabar. Koran tersebut memilih menggunakan jenis huruf pada halaman muka surat kabarnya seperti huruf palatino, helvetika dan jenis huruf black. letter atau dengan sebutan old english. Penggunaan Jenis huruf black. letter atau dengan sebutan old english, juga dilakukan oleh surat kabar Thairath pada logonya terlihat pada tipe hurufnya yang tebal.

Para desainer juga melakukan desain pada huruf yang akan digunakan pada bagian headline, agar memiliki nilai "kontras huruf dan kreativitas". Pemilihan dan pendesainan huruf untuk kerativitas visual dengan melakukan kombinasi huruf. Karena headline merupakan salah satu unit informasi yang harus dimunculkan. Desainer dapat menciptakan kontras dengan mengombinasikan kategori huruf dengan menekan pada kata dan menggunakan warna serta mengubah penampilan huruf. Menciptakan penekanan kata pada beadline dapat dilakukan dengan mengubah ukuran, warna, dan postur huruf. Kata yang akan ditekankan harus dipilih dengan cermat agar efektif dan sesuai isi berita. Warna juga dapat membawa pembaca untuk memerhatikan satu bagian dari beadline tertentu. Mengulang warna untuk teks atau subjudul akan memberi kesan bahwa berita itu adalah satu kesatuan dalam kelompok. Mata pembaca cenderung mengelompokkan sesuatu berdasarkan warna dan bentuk, seperti yang dilakukan oleh surat kabar Thairath pada bagian headlinenya.

Berdasarkan dari hasil wawancara dengan informan, dapat dijelaskan bahwa, penggunaan huruf pada kedua surat kabar itu, dilakukan dengan menggunakan berbagai jenis huruf secara konsisten pada setiap bagian dalam halaman mukanya. Desainer juga melakukan desain huruf pada bagian tertentu, supaya huruf yang disajikan lebih menarik dan memikat perhatian pembaca.

Berdasarkan pandangan peneliti tentang tipografi yang digunakan pada halaman muka surat kabar Thairath yang menggunakan ukuran huruf pada judul berita lainnnya yang hampir sama dengan ukuran huruf judul berita utama. Teks judul, kutipan dan subjudul harus muncul dalam ukuran yang lebih kecil ketimbang ukuran huruf pada headline. Oleh karena itu, desainer harus memilih ukuran dan postur huruf untuk menarik perhatian pembaca ke tipe penampilan terbesar dan kemudian ke tipe selanjutnya secara logis (Rolnicki, 2008: 242).

Aspek lainnya dari reka bentuk adalah tata letak. Berdasarkan penjelasan tentang perwajahan dan tata letak, dua hal yang tidak terpisah dari reka bentuk media cetak. Semakin menarik dan estetis perwajahan dan penataan pada media cetak, maka semakin tinggi daya pikatnya. Penataan halaman muka surat kabar, selain untuk memikat pembaca juga untuk membuat pembaca lebih nyaman dalam mencerna informasi. Layout mempunyai peranan yang penting karena hasil karya 
layout inilah yang akan berhadapan langsung dengan pembaca. Jika layout itu bagus dan menarik akan menimbulkan daya tarik tersendiri bagi masyarakat, karena sebelum pembaca membeli, terlebih dahulu mereka akan melihat isi dari surat kabar tersebut melalui penampilannya (Djuroto, 2004: 30).

Mengemas perwajahan dan tata letak surat kabar merupakan kegiatan desain grafis yang bertujuan untuk menghias halaman surat kabar sehingga memiliki daya tarik, namun dalam mengemaskan desain grafis ini terdapat prinsip-prinsip desain dalam melakukan proses perwajahan dan perancangan tata letak media cetak.

Ada enam prinsip desain yang baik yaitu, keseimbangan, ritme, kepaduan, skala, proporsi dan hirarki visual. Sedangkan dalam design Principle for Desktop Publishing, ada lima prinsip utama dalam desain yaitu: proporsi, keseimbangan, kontras, irama dan unity (Rolnicki, 2008: 256).

Dunia desain grafis sistem grid atau garis sudah tidak asing, bahkan sangat terkenal dan bisa membantu para desainer ketika menata halaman surat kabar. Oleh karena itu, sistem kisi atau grid dapat dikatakan sebagai kegiatan mereka-reka membentuk halaman surat kabar.

Proses pembuatan grid diilhami oleh lukisan karya Piet Mondrian. Dalam lukisan itu nampak lebih dominan penggunaan garis-garis (grid) sebagai alat bantu dalam mendesain halaman. Bahkan, desainer kertas Oti Aicher seorang desainer pertama yang menciptakan simbol-simbol cabang olahraga pada Olimpiade Munich 1972 dengan menggunakan sistem grid. Dalam melakukan sistem grid pada halaman, setidaknya harus memperhatikan empat elemen mendasar yaitu, judul (headline), teks, gambar dan halaman kertas kosong (Kusrianto dalam Darsono dan Muhaemin, 2013: 74).

Layout atau tata letak terbagi ke dalam tujuh jenis diantaranya, symitrical layout, informal balance layout, quadran layout, brace layout, circus layout, horizontal layout, function layout (Ipit Zulfan dalam Darsono dan Muhaemin 2013 : 77).

Berdasarkan pendangan peneliti dari hasil pengamatan dokumen serta hasil wawancara, dapat dijelaskan, pelaksanaan penataan layout dilakukan dengan tujuan untuk meletakkan elemen yang akan disajikan dalam halaman muka. Layout yang digunakan pada media cetak Tribun Jabar dilakukan sebagai ciri khas medianya. Penempatan elemen pada halaman muka tidak terlepas dari ciri khas layout yang telah disepakati dalam perusahaannya.

Layout pada surat kabar Thairath cenderung memainkan berbagai elemen pada halaman mukanya. Berdasarkan beberapa pendapat para ahli mengenai layout, maka dapat simpulkan, layout yang digunakan surat kabar Thairath adalah tampilan layout youthful style yaitu suatu bentu layout yang memiliki kesan lucu, main-mainan dan penulisan berita headline dilakukan dengan berbagai ukuran. Pada sisi lain, 
Thairat juga menggunakan Quadran Layout yaitu tata letak segi empat, karena apabila surat kabar ini dilipat empat, pada seperempat bagian yang tampak itu akan diperlihatkan berita pentingnya. Juga menggunakan function Layout karena tata telak yang setiap hari berubah, tergantung pada pekembangan dan isi berita pada hari itu. Bila terjadi hal-hal yang luar biasa, sering dipakai apa yang disebut "skyline heads", jadi ada pemindahan nama surat kabar itu sendiri.

\section{PENUTUP}

Warna yang digunakan pada halaman muka kedua surat kabar, baik surat kabar Thailand yaitu Thairath dan surat kabar Tribun Jabar, mempunyai warna identitas perusahaan dan digunakan dalam halaman muka surat kabar. Penggunaan warna dominan digunakan pada logo untuk menunjukkan warna identitas surat kabar. Warna lain juga digunakan pada halaman muka surat kabar yang bukan sekadar pada logonya.

Tipografi surat kabar Thairath dan surat kabar Tribun Jabar dilakukan secara konsisten pada setiap bagian pada halaman muka, seperti headline, subjudul, isi berita dan caption. Dengan menggunakan tipografi yang berbeda-beda ukuran sesuai dengan bagiannya. Selanjutnya mengikuti hierarki visual, namun yang menjadi perbedaan dalam penggunaan tipografi pada kedua surat kabar ini adalah warna tipografi halaman muka. Surat kabar Thairath menggunakan dua warna pada halaman mukanya yaitu hitam dan putih. Tribun Jabar dominan menggunakan warna huruf hitam dan hanya beberapa warna lain yang digunakan tergantung jenis berita.

Tata letak surat kabar Thairath dan surat kabar Tribun Jabar, dilakukan sesuai dengan kebijakan yang dijadikan aturan dalam penataan layoutnya dan sesuai dengan format surat kabar. Penataan layout juga dilakukan sesuai dengan kelompok segmentasi yang menjadi sasaran bagi surat kabar, yang tampak pada layout kedua surat kabar tersebut. Penataan layout yang dilakukan secara ketat oleh Thairath pada halaman dengan memainkan warna, foto dan tipografi. Sementara penataan layout pada halaman muka Tribun Jabar, dilakukan secara fleksibel, tidak terlalu banyak dalam memainkan warna dan foto.

\section{DAFTAR PUSTAKA}

Arham., Koagouw, F.V.I.A., \& Onsu, R. (2018). Pengaruh Desain Komunikasi Visual Surat Kabar Manado Post terhadap Keputusan Membaca Mahasiswa Ilmu Komunikasi Fakultas Ilmu Sosial dan Politik Universitas Sam Ratulangi. Jurnal Acta Diurna Komunikasi, 7(2), 1-11. 
https://ejournal.unsrat.ac.id/index.php/actadiurnakomunikasi/issue/view /1956/showToc

Arianti, G., Slamet, A.S., \& Andrianto, M.S. (2017). Analisis Kepuasan Pelanggan Surat Kabar Harian Pagi Radar Bogor. Jurnal Kolegial, 5(1), 51-61. http://journals.stiedwisakti.ac.id/ojs/index.php/kolegial/issue/view/4

Darsono, D., \& Muhaemin, E. (2013). Reka Bentuk Media Cetak Antara Perwajahan dan Tata letak. Bandung: Mimbar Pustaka.

Darsono, D. dan Muhaemin, E. (2012) Secangkir Peristiwa Di mata Wartawan. Bandung : Mimbar Pustaka.

Djuroto, T. (2002). Manajemen Penerbitan Pers. PT. Rosdakarya: Bandung.

Effendy, O.U. (2002). Ilmu Komunikasi: Teori dan Praktik. Bandung: Remaja Rosdakarya.

Hardiansyah., Arifin, I., \& Aswar. (2017). Desain dan Perwajahan Majalah Kurva Desain Komunikasi Visual. Jurnal Imajinasi, Seni dan Pendidikan Seni, 1(2). https://ojs.unm.ac.id/imajinasi/issue/view/823

Khalik, A. (2018). Penerapan Reka Bentuk Halaman Muka Surat Kabar. Jurnal Communicology: Jurnal Ilmu Komunikasi, 16(2): 35-53.

Kristiana, N. (2016). Tinjauan Tata Letak Surat Kabar Harian Lokal (Analisis Isi dan Hierarchi). Jurnal Dekave, 9(2), 54-66. DOI: https://doi.org/10.24821/dkv.v9i2.1764

Kurnianto, A. (2013). Analisis Layout Surat Kabar Berdasarkan Prinsip-Prinsip Desain Melalui Metode Estetika Birkhoff. HUMANIORA, 4(2), 986-994.

Kusrianto, A. (2009). Pengantar Desain Komunikasi Visual, Yogyakarta: Andi.

Mahardika, R. (2016). Analisis Struktur dan Proses Komunikasi pada Seri Iklan Billboard Surat Kabar Kedaulatan Rakyat (Tema "Bebarengan Mrantasi Gawe" Versi Mbok Gendong). Jurnal Dimensi DKV, 1(1), 25-34. https://trijurnal.lemlit.trisakti.ac.id/seni/issue/view/82/show'Toc

Mahdamy, A. (2015). Perancangan Visualisasi Perwajahan dan Media Promosi Buku City Branding untuk Kotal Kabupaten di Indonesia. Tugas Akhir, Jurusan Desain Komunikasi Visual, Universitas Negeri Solo.

Mulyana, D. (2010). Ilmu Komunkasi Suatu pengantar. Bandung: PT Remaja Rosdakarya.

Padmasari, C.V. (2018). Studi Perubahan Desain Tata Letak Surat Kabar Harian "Kompas" Tabun 1965 - 2015. Thesis, Institut Seni Indonesia Yogyakarta.

W.H., Prayanto. (2017). Peranan Foto dalam Perwajahan Majalah. Jurnal Imaji Seni dan Pendidikan Seni, 5(2): 185-195. DOI: https://doi.org/10.21831/imaji.v5i1.6682

Rahman, A. (2016). Strategi Koran SINDO Makassar Menggait Pembaca Melalui 
Miss Aminah Sa-ah

Perwajaban Halaman Satu. Skripsi, UIN Alauddin Makassar.

Rolnicki, T.E., Tate, C. D., \& Taylor, S.A. (2008). Pengantar Dasar Jurnalistisme (Scholastic Journalism). Jakata: Kencana Prenada Media Grup.

Rustandi, A. (2006). Perubahan Format dan Desain Surat Kabar Indonesia dalam

Perspektif McJournalism. Mediator: Jumal Komunikasi, 7(2), 235-242. DOI:

https://doi.org/10.29313/mediator.v7i2.1278

Syuderajat, F. (2017). Ideologi Surat Kabar dalam Pemberitaan Terorisme, Communicatus: Jurnal Ilmu Komunikasi, 1(1), 1-12. DOI: https://doi.org/10.15575/cjik.v1i1.1206

Widigda, G.R., \& Zaini, I. (2017). Analisis Konsep, Struktur Visual Layout "Deteksi" Pada Harian Jawa Pos Edisi 15 April - 15 Mei 2014. Jurnal Seni Rupa, 5(2).

https://jurnalmahasiswa.unesa.ac.id/index.php/va/issue/view/1234

Yuningsih, Y. (2009). Peranan Perawajahan dalam Surat Kabar. Emphaty: Jurnal Komunikasi, 3(7), 607-610. 